\title{
Cecocolic intussusception and cecal torsion in cattle
}

\author{
Intussuscepção cecocólica e torção de ceco em bovinos \\ Ângela Imperiano da Conceição ${ }^{1 *} \oplus^{\circ}$, José Ricardo Barboza Silva² ${ }^{\circ}$, \\ Uila Almeida Aragão de Alcantara ${ }^{3} \odot$, Carla Lopes de Mendonça ${ }^{4} \odot$, Luiz Teles Coutinho ${ }^{\oplus} \odot$, \\ Jobson Filipe de Paula Cajueiro ${ }^{4} \odot$, Rodolfo José Cavalcanti Souto ${ }^{4}{ }^{\oplus}$, José Augusto Bastos Afonso 4
}

\begin{abstract}
This work aims to describe the clinical, laboratory, and anatomopathological findings of two bovines, one affected by cecocolic intussusception, and the other by dilation with cecal torsion. The clinical examination demonstrated metallic resonance from the right flank, ruminal and intestinal hypomotility, and abdominal distension, in addition to alterations in feces characteristics. Was observed in the two animals leukocytosis by neutrophilia with regenerative shift to the left, and hyperfibrinogenemia. The analysis of ruminal fluid revealed impairment of the microbiota and an increase in chloride levels. The laparoscopic examination performed on one of the animals showed dilation of the colon, the cecum with hyperemia and serous edema, with a dividing halo between affected and unaffected portions, in addition to reddish peritoneal fluid. In the laparotomy, an enlarged cecum was found, with gaseous and liquid contents, swollen and turgid colon, and peritonitis. In addition to the findings observed during surgery, the anatomopathological examination demonstrated, in bovine 01 , intestinal intussusception in the region of the cecocolic valve, and, in bovine 02, twisting of the loop at the ileocecocolic junction. Despite the low occurrence of digestive system disorders in cattle, cecal torsion and intussusception represent serious intestinal clinical conditions. These reports take the attention to the importance of a multidisciplinary approach to provide a correct diagnosis of intestinal diseases.
\end{abstract}

KEYWORDS: Bowel obstruction; Digestive system; Laparoscopy; Digestive disorder.

RESUMO: O objetivo deste trabalho foi descrever os achados clínicos, laboratoriais e anatomopatológicos de dois bovinos, um acometido por intussuscepção cecocólica e o outro por dilatação com torção de ceco. O diagnóstico de ambos os casos foi baseado nos achados clínicos, laboratoriais, videolaparoscópicos, cirúrgicos e anatomopatológicos. No exame clínico evidenciou-se ressonância metálica no flanco direito, hipomotilidade ruminal e intestinal, distensão abdominal, além de alteração nas características das fezes. Observou-se nos dois animais leucocitose por neutrofilia com desvio para esquerda regenerativo e hiperfibrinogenia. A análise do fluido ruminal revelou comprometimento da microbiota e elevação nos teores de cloretos. O exame videolaparoscópico, realizado no bovino dois (02), evidenciou dilataçáo do cólon, ceco com hiperemia e edema de serosa com halo divisório entre porção acometida e não acometida, além de líquido peritoneal de coloração avermelhada. Na laparotomia constatou-se ceco dilatado por conteúdo gasoso e líquido, cólon edemaciado e túrgido e, peritonite. No exame anatomopatológico, constatou-se, no bovino um (01), intussuscepção intestinal na região de válvula ceco-cólica e, no bovino (02) torção de alça na junção ileocecocólica. Apesar da baixa ocorrência, a torção de ceco e a intussuscepçáo acarretam condição intestinal grave e devem ser inseridas na lista de diagnósticos diferenciais das enfermidades digestivas de bovinos. Estes relatos chamam a atenção para a importância da abordagem multidisciplinar no diagnóstico das enfermidades intestinais.

PALAVRAS-CHAVE: Laparoscopia; Obstrução intestinal; Sistema digestório; Transtornos obstrutivos.

\section{INTRODUCTION}

Although they occur less commonly than forestomach and abomasum diseases in bovines, dilatation, torsion, and intussusception of the cecum are highlighted as causes of digestive dysfunctions, representing a diagnostic challenge, and economic losses to dairy production (ANDERSON,
2008; AFONSO, 2017). Intussusception is more frequent in the small intestine, and more common in young animals, although there is no predisposition by breed, sex, or seasonality (PRAVETTONI et al., 2009; CONSTABLE et al., 2017). In contrast, cecal dilatation, in addition to other fermentative disorders occurs mainly in cows with high milk production

\footnotetext{
${ }^{1}$ Graduate Program in Veterinary Medicine, Federal Rural University of Pernambuco, Recife/PE, Brazil.

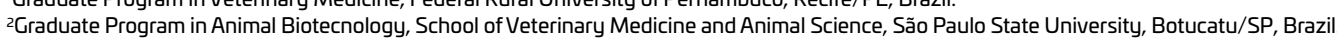

${ }^{3}$ Graduate Program in in Health and Breeding of Production Animals, Federal Rural University of Pernambuco, Garanhuns/PE, Brazil.

${ }^{4}$ Garanhuns Clinic of Cattle, Federal Rural University of Pernambuco, Garanhuns/PE, Brazil.

*Corresponding author: angelaimperiano@hotmail.com

Received: 04/03/2021. Accepted: 15/05/2021
} 
reared under intensive systems (AFONSO; MENDONÇA, 2007; BARROS et al., 2010).

Diets rich in carbohydrates can lead to incomplete fermentation in the pre-stomachs, when the contents reach the cecum compartment, they are fermented by the flora in the cecum, increasing the concentration of volatile fatty acids (VFA), decreasing the $\mathrm{pH}$ in the organ's content and leading to atony, causing the accumulation of gas and liquid (AFONSO, 2017; CONSTABLE et al., 2017).

Intussusception is implicated in conditions that alter intestinal motility, resulting in hyperperistalsis in the oral segment, associated with the relaxation of the distal segment, like, parasitism; sudden alterations in diet; enteritis (bacterial or viral) and intestinal injury associated with distal segment relaxation (ANDERSON, 2008; OKAMOTO et al., 2007; SILVA FILHO et al., 2010). Although the diagnosis can be made through the association of anamnesis, clinical signs, and complementary exams, it is usually performed during an exploratory laparotomy, or anatomopathological findings. However, a minimally invasive approach, such as laparoscopy, can be used as a resource in the diagnosis of digestive diseases (SILVA, 2018).

This work aims to describe the clinical, laboratory and anatomopathological findings, observed in two bovines, one had a diagnosis of ceco-colic intussusception and another cecal dilatation/torsion.

\section{CASE REPORT}

The information refers to two bovines, females, adults, reared in a semi-intensive system, with updated vaccination (rabies, foot and mouth disease, clostridiosis and brucellosis) and deworming, attended at the Bovine Clinic of Garanhuns, Campus of the Federal Rural University of Pernambuco (CBG / UFRPE). Animal 01 (Holstein) received a diet composed of corn silage, sugar cane, (soybean, cotton and corn bran, $2 \mathrm{~kg} /$ day), while animal 02 (crossbreed Holstein $\mathrm{x}$ Zebu) was fed with native pasture, cassava bark $(5 \mathrm{~kg} /$ day $)$, soybean and corn barn $(7 \mathrm{~kg} /$ day $)$. There was no change in the feeding of the first animal, however for the second animal, there was an additional supply of crushed sugar cane $(2 \mathrm{~kg})$.

The owners reported a history of lack of appetite, colic, decreased milk production and reduced fecal output. The bovine 01 also presented mucus and blood in the feces, and bovine 02 , bilateral abdominal distension. Still on the farms, the animals were treated with anti-inflammatory, antibiotic, and multivitamin solution for their respective owners, but did not show signs of improvement. Thus, animals 01 and 02 , were attended at the veterinary hospital, after 2 and 3 days of clinical evolution, respectively.

At the clinical examination (DIRKSEN; GRÜNDER; STÖBER, 1993), was observed that the animals were moderate dehydration, tachycardia, without fever, however, the most relevant clinical findings were related to the gastrointestinal tract (Table 1).

Peritoneal fluid collection was attempted in both animals, according to literature (DIVERS; PEEK, 2008), and was unproductive. Blood samples to perform the cell blood count, plasma determination of total protein, and fibrinogen were processed according to literature (HARVEY, 2012), which revealed, in bovine 01 , normochromic normocytic anemia, hypoproteinemia, and mild leukocytosis $(12,100 / \mu \mathrm{l})$ through neutrophilia with regenerative shift to the left, besides the inversion of the neutrophil to lymphocyte ratio. Bovine 02 presented hyperfibrinogenemia and leukocytosis $(18,600 /$ $\mu \mathrm{l})$ due to lymphocytosis and neutrophilia, with slight deviation to the left. Analyses of ruminal fluids with determination of chloride contents were also performed (BARROS et al, 2010; DIRKSEN; GRÜNDER; STÖBER, 1993), which showed impairment of microbiota and increased chloride levels (Table 2).

In animal 02, exploratory laparoscopy was also performed, following literature (BOURÉ, 1995), using equipment for Telepack Vet video surgery, Karl Storz Veterinary Endoscopy, which had an LED (Light emitting diode) light source, connected to a $10 \mathrm{~mm}$ fiber optic cable, microcamera attached to a monitor, and $\mathrm{CO}_{2}$ insufflator (Karl Storz Veterinary Endoscopy), with controlled pressure and temperature. The images showed a distended colon, intestinal serous with hyperemia and edema, increased peritoneal fluid, and a reddish color (Figure 1).

Table 1. I Clinical information of cattle affected by Cecocolic Intussusception (bovine 01) and Cecal Torsion (bovine 02).

\begin{tabular}{l|c|c}
\hline & \multicolumn{2}{|c}{ Clinical-pathological alterations } \\
\hline Variables & Bovine 01 & Bovine 02 \\
\hline Rectal temperature & $37.8^{\circ} \mathrm{C}$ & $39.4^{\circ} \mathrm{C}$ \\
\hline Apetite & normal & normal \\
\hline Heart rate & $112 \mathrm{bpm}$ & $88 \mathrm{bpm}$ \\
\hline Ruminal motility & $\begin{array}{l}\text { Incom } \\
\text { Movements }\end{array}$ & $\begin{array}{c}\text { Incom } \\
\text { Movements }\end{array}$ \\
\hline Intestinal motility & Hypomotilic & Hypomotilic \\
\hline Abdominal distension & Present & Present \\
\hline $\begin{array}{l}\text { Metallic “Ping” from the } \\
\text { right flank }\end{array}$ & Present & Present \\
\hline Splashing (Liquid) & Present & Present \\
\hline Colic & Present & Present \\
\hline Abdominal tension & Increased & Physiological \\
\hline Feces & Scarce & Scarce \\
\hline Mucus and blood in the & Present & Present \\
feces & &
\end{tabular}

aDirksen; Gründer; Stöber, 1993. 
Table 2. Microbiota impairment and chlorides level increase in ruminal fluid at bovine 01 and 02.

\begin{tabular}{l|c|c|c} 
Parameters & Bovine 01 & Bovine 02 & $\begin{array}{c}\text { Reference } \\
\text { values }^{\mathrm{a}}\end{array}$ \\
\hline Color & Brown & Olive green & Olive green \\
\hline Odor & Aromatic & Aromatic & Aromatic \\
\hline Consistency & $\begin{array}{c}\text { Slightly } \\
\text { viscous }\end{array}$ & $\begin{array}{c}\text { Slightly } \\
\text { viscous }\end{array}$ & $\begin{array}{c}\text { Slightly } \\
\text { viscous }\end{array}$ \\
\hline $\mathrm{pH}$ & 8.0 & 7.0 & $5.5-7.0$ \\
\hline Live Infusoria (\%) & 25 & 30 & 100 \\
\hline Density & Moderate & Moderate & High \\
\hline Motility & Moderate & Moderate & High \\
\hline MBR (minutes) ${ }^{\mathrm{b}}$ & 8 & $5^{\prime}: 30^{\prime \prime}$ & $<3.0$ \\
\hline $\begin{array}{l}\text { Chloride Content } \\
\text { (mEq/L) }\end{array}$ & 45.81 & 34.04 & $<30$ \\
\hline
\end{tabular}

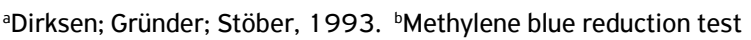

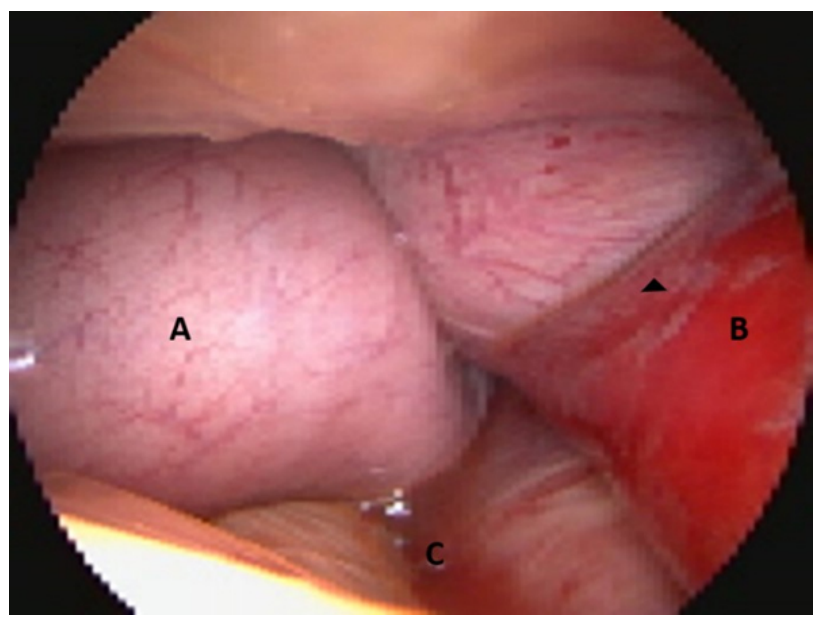

Figure 1. Bovine exploratory laparoscopic examination. (A) cecal segment with torsion, presenting dilation; (B) colon segment presenting intense hyperemia and serous edema, with the region of intersection (arrow head) between affected and non-affected portion; (C) reddish peritoneal fluid.

In view of the findings, the clinical suspicions of both cases were cecum dilation, and in both cases the therapeutic decision was surgical, with an exploratory laparotomy being performed on the right side, according to literature (FUBINI; DUCHARME, 2017).

In the exploration of the cavity of animal 01 , a large amount of fibrin deposit was found in the serosa of the organs, as well as free filaments in the abdominal fluid, which was increased and amber yellow. The cecum was markedly dilated with a large amount of gaseous and liquid content; the colon was increased in volume (20 to $30 \mathrm{~cm}$ ), swollen and turgid in its proximal portion to the cecum. After exposure of the cecum, typhlotomy was performed with spontaneous or by massaging approximately 15 liters of brown colored content with a fetid odor. Next, the cecum was irrigated with abundant saline and oxytetracycline solution and being replaced to the cavity. Unsuccessful attempts were made to expose the compromised portion of the colon for better evaluation.

The postoperative management consisted of anti-inflammatory (Flunixin meglumine, $2,2 \mathrm{mg} / \mathrm{kg}$, IV, five applications with a 24-hour interval), metoclopramide $(0.3 \mathrm{mg} / \mathrm{kg}$, SC, three applications with a 24-hour interval), Ceftiofur $(1 \mathrm{mg} / \mathrm{kg}$, IM, seven applications with a 24-hour interval), and daily surgical wound care. The use of adjuvant therapy, with mandacaru (Cereus jamacaru) juice, calcium borogluconate solution, and omeprazole was implemented. Despite this treatment, clinical evolution was unsatisfactory, with the addition of apathy, anorexia, and increased abdominal tension to the previously mentioned signs. Due to the worsening of the clinical condition euthanasia was performed after 5 days of treatment.

In bovine 02 , exploration of the abdominal cavity showed an increase in the volume of peritoneal fluid, which had supernatant fibrin tags, diffuse fibrous adhesions between the cecum and right abdominal wall, greater omentum, ventral floor of the right abdomen, and large intestine. The cecum was in the shape of an "S," intensely distended by gaseous and liquid contents, with its apex directed in the ventral and cranial direction of the abdominal cavity. In the region of the base of the cecum, there was still intense edema and adherence with a segment of the loop of the proximal colon, which presented congestion and cyanosis of the serosa. The cranial intestinal segment (small intestine) to the cecum was full and hypomotilic; the colon was empty. Due to the findings that revealed signs of cecal torsion or cecocolic intussusception, and the degree of visceral damage that made the correction unfeasible, in addition to peritonitis, euthanasia was performed, after surgery.

The necropsy of bovine 01 revealed, in the abdominal cavity, a marked increase in the volume of the peritoneal fluid, which had an amber color, the presence of free fibrin debris, and a fetid odor, diffuse fibrin-purulent reaction, multiple adhesions between the serosa of the abdominal organs and these with the peritoneum, diaphragm, and greater omentum. An intestinal intussusception was found in the region of the cecocolic junction, which contained friable and congested contents, in addition to clots (Figure 2).

At necropsy of bovine 02 , focal extensive serofibrinous peritonitis was observed (Figure 3), with the presence of fibrin in the serosa of the cecum and colon; greater omentum of diffusely red and the presence of fibrin; intense cecal dilation, smooth and shiny serosal surface with ecchymosis and suffusions in the multifocal serosa. At the ileocecocolic junction, there was torsion, with the presence of a cyanotic halo, with friable tissue, fibrin adhesions. In the mucosa, in addition to the necrosis halo, there were ulcers and hemorrhages. 


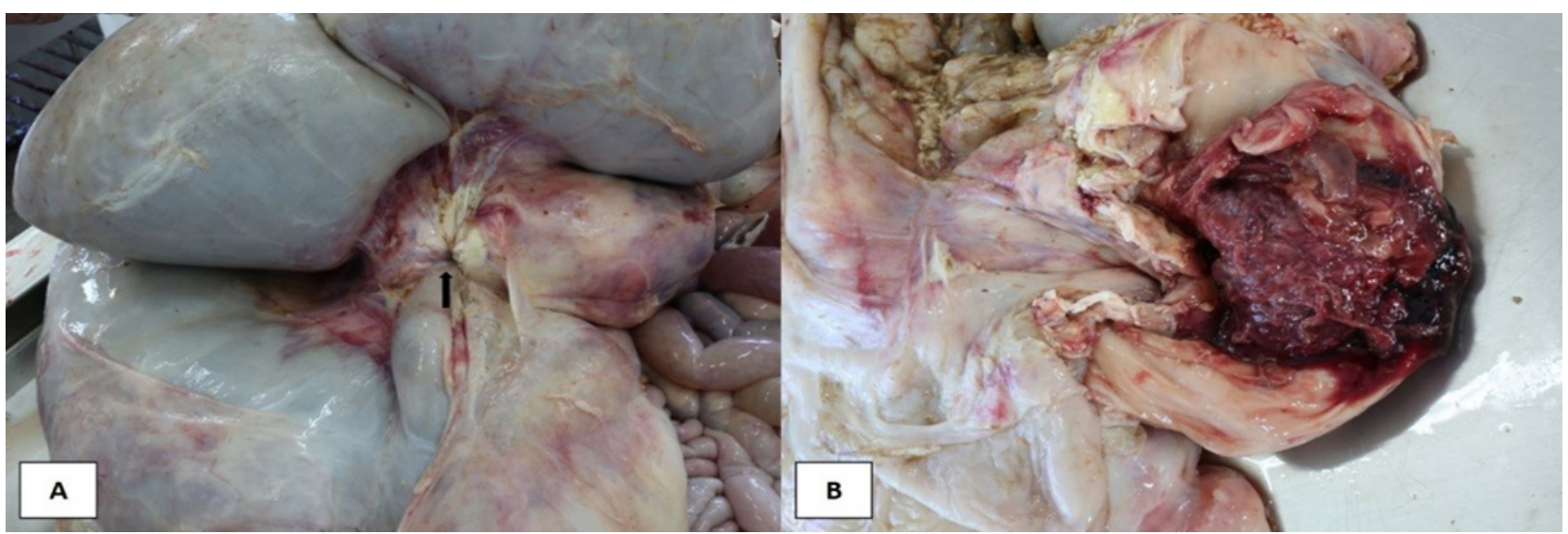

Figure 2. Anatomopathological examination of bovine: (A) cecocolic intussusception (arrow); (B) intussuscepted content presenting clots and necrosis.

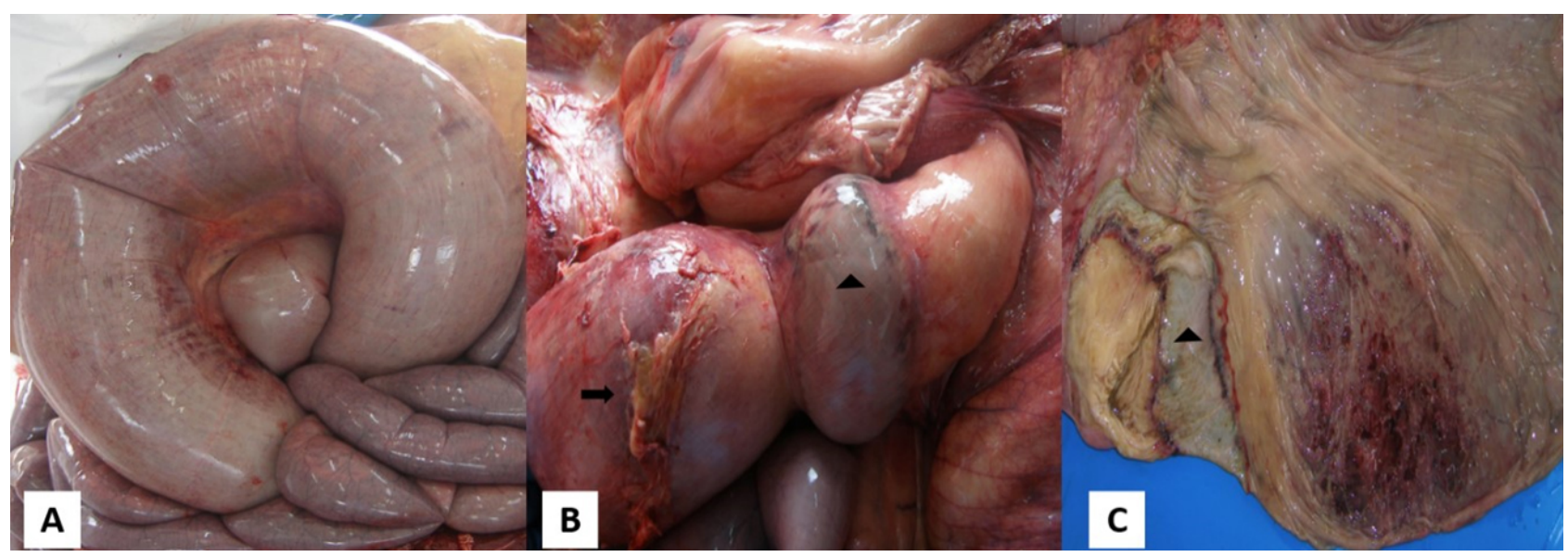

Figure 3. Anatomopathological findings: $(A)$ intensely dilated cecum with ecchymosis on the serosa; (B) torsion of the loop at the ileocecolic junction with the presence of a cyanotic halo (arrow head) in the adjacent tissue and fibrin adhesions close to the torsion region (arrow); (C) cecal mucosa presenting ulcer and area of intense circulatory impairment and cyanotic halo region (arrow head).

\section{DISCUSSION AND CONCLUSIONS}

Among the digestive system disorders in cattle, dilatation of the cecum and intussusception, despite the low incidence, represent serious intestinal clinical conditions. The still underreported etiology of these diseases promotes a consensus of multifactorial cause, in which factors that lead to alterations in intestinal motility are present, such as changes in diet (animal 01 ) or the supply of high energy density diets (animal 02) (AFONSO; COSTA, 2007; SILVA FILHO et al, 2010).

The above-mentioned clinical signs have also been found in other studies (AFONSO et al., 2002; LEJEUNE; KRAMER; MEYLAN, 2015; SILVA FILHO et al, 2010; SILVA et al., 2014). Tachycardia and colic occur mainly because of intestinal distention due to the trapped content associated with the production of gas by bacteria, activating nociceptive receptors in the intestinal wall, which promotes evident signs of visceral pain. The continuation of these distention results in the local blood supply being compromised by vessel compression, culminating in ischemic necrosis, cell death, and peritonitis or both. After necrosis, in these situations, pain signals may not be shown (AFONSO, 2017; IMRAN et al., 2011).

Abdominal distension is commonly seen with the progression of the disease, and is due to the efflux and distention of the intestines, abomasum, and pre-stomachs by gas and liquid, in addition to the sequestration of liquid by ingestion in the gastrointestinal tract, resulting in progressive dehydration and electrolytic depletion. Fecal output can be normal or decreased for up to $12-24 \mathrm{~h}$ after the obstructive process occurs. The passage of blood and mucus from the rectum is common from this moment on (ANDERSON, 2008; AFONSO, 2017; BRAUN et al., 2012).

High values of chloride concentration in the rumen $(>30 \mathrm{mEq} / \mathrm{L}$ ) are found in situations where the rumen is distended by excess liquid, resulting from an abomasal reflux, on cecal dilatation is less intense. In addition, changes in physical and chemical characteristics and impairment in ruminal 
microbiota are justified by the debilitating and serious nature of the diseases, which decrease food intake (ANDERSON, 2008; AFONSO et al, 2002; BARROS et al, 2010).

Hematological parameters showing inflammatory leukogram, with a deviation to the left and inversion of the neutrophil to lymphocyte ratio or both, in addition to hyperfibrinogenemia, can be explained by the lesion in the wall of the loops. Thus, the magnitude of these alterations depends on the extent and duration of the injury (AFONSO; COSTA, 2007; AGNE et al., 2018; BRAUN et al., 2012; SILVA FILHO et al, 2010).

In both cases, anatomopathological exams were decisive for elucidating the diagnoses of cecocolic intussusception (bovine 01) and cecal torsion (bovine 02). The findings were compatible with the previously observed clinical, hematological, and laparoscopic alterations, highlighting the severity of the involvement of affected organs (circulatory and inflammatory alterations), with peritonitis, frequently mentioned in studies, being one of the main consequences due to alterations in the permeability of the wall (AFONSO, 2017; AGNE et al., 2018; SILVA et al., 2014).

Thus, the importance and severity of intussusception and cecal torsion in adult cattle is reiterated, considering the poor prognosis of booth diseases, as well as the importance of the multidisciplinary approach (anamnesis, clinical findings, anatomopathological and complementary exams) to facilitate a correct diagnosis of these diseases.

\section{REFERENCES}

AFONSO, J. A. B. et al. Alterações clínicas e laboratoriais na dilatação do ceco em bovinos. Análise de 10 casos. Revista de Educacão Continuada, CRMV-SP, v. 5, n. 3, p. 313-320, 2002.

AFONSO, J. A. B.; COSTA, N. A. Doenças não transmissíveis do trato digestivo dos ruminantes: obstrução intestinal em bovinos. In: RIETCORREA, F. et al. (Ed.). Doenças de ruminantes e equídeos. 3. ed. Santa Maria: Palloti, 2007.

AFONSO, J. A. B. Afecções intestinais em bovinos. Revista Academica, v. 2, p.15-20, 2017.

AFONSO, J. A. B.; MENDONÇA, C. L. Dilatação do ceco. In: RIETCORREA, F. et al. (Ed.). Doenças de ruminantes e equídeos. 3. ed. Santa Maria: Palloti, 2007.

AGNE, G. F. et al. Successful surgical resolution of a ceco-cecal intussusception in a 15-month-old Angus heifer. Canadian Veterinary Journal, v. 59, p. 1071-1074, 2018;

ANDERSON, D. E. Surgical diseases of the small intestine. Vetinary Clinics of NorthAmerica:FoodAnimal Practice, v. 24, p. 383-401, 2008.

BARROS, I. O. et al. Intussuscepção tipo colíco em bovino provocada por corpo estranho: relato de caso. Acta Veterinaria Brasilica, v. 4, п. 3, p. 203-209, 2010.

BOURÉ, L. General principles of laparoscopy. Veterinary Clinics of North America: Food Animal Practice, v. 21, p. 227-249, 2005.

BRAUNU. et al. Clinical findings and treatment in cattle with caecal dilatation. BMC Veterinary Research, v. 8, n. 1, p. 75, 2012.

CONSTABLE, P.D. etal. Veterinary Medicine:ATextbook of the Diseases of Cattle, Horses, Sheep, Pigs, and Goats. ll. ed. Missouri: Elsevier, 2017.

DIRKSEN, G.; GRÜNDER, H. D.; STÖBER, M. Rosenberger: exame clínico dos bovinos. 3. ed. Rio de Janeiro: Guanabara Koogan, 1993.
DIVERS, T. J.; PEEK, S. F. Rebhun's Diseases of Dairy Cattle. 2. ed. Missouri: Elsevier, 2008.

FUBINI, S. L.; DUCHARME, N. G. Farm Animal Surgery. 2. ed. Missouri: Elsevier, 2017.

HARVEY, J.W. Hematology procedures. In: HARVEY, J.W. Veterinary hematology. A diagnostic guide and color atlas. St. Louis: Elsevier, 2012.

IMRAN, S. et al. Usefulness and limitation of ultrasonography in the diagnosis of intestinal intussusception in cows. Veterinary Medicine International, p. 1-6, 2011.

LEJEUNE, B.; KRAMER, A.; MEYLAN, M. Caeco-caecale invagination bei einem Simmentaler Rind. Schweizer Archeiv für Tierheilkunde, v. 157, n. 7, p. 401-405, 2015.

OKАMOTO M. et al. Intussusception of the spiral colon associated with fibroserous granulation in a heifer. Veterinary Record, v. 17, p. 376-378, 2007.

PRAVETTONI, D. et al. Repeated occurrence of jejuno-jejunal intussusception in a calf. Canadian Veterinary Journal, v. 50, п. 3, p. 287-290, 2009.

SILVA FILHO, A. P. et al. Análise clínica e patológica em 20 casos de intussuscepção em bovinos. Veterinária e Zootecnia, v. 17, п. 3, p. 421-430, 2010.

SILVA, J. R. B. Videolaparoscopia e ultrassonografia como métodos auxiliares no diagnóstico das enfermidades abdominais dos bovinos. Dissertação (Mestrado) - Universidade Estadual Paulista "Júlio de Mesquita Filho", Faculdade de Medicina Veterinária e Zootecnia, Botucatu, 2018.

SILVA, R. J. et al. Dilatação do ceco em bezerros: relato de casos. Revista Brasileira Ciência Veterinária, v. 2l, n. 2, p. 76-81, 2014. 